UDC 378.011.3-051

DOI: $10.31470 / 2415-3729-2019-9-211-225$

\title{
Professional Training of a Teacher to the Practical Realization of the Idea of the New Ukrainian School
}

\section{Olena Khmelnytska}

Doctor of Philosophy in Pedagogy (Ph.D),

Senior Lecturer at the Department of Pedagogy

Pereiaslav-Khmelnytskyi Hryhorii Skovoroda State

Pedagogical University,

$\bowtie$ 30, Sukhomlynskyi Str., Pereiaslav-Khmelnytskyi, Kyiv

Region, Ukraine, 08401

E-mail: hmelnitskalena@ukr.net

ORCID: 0000-0002-0644-6201

Date of receipt of the article: November 30, 2018

Article accepted for publication: February 21, 2019

\section{Професійна підготовка педагога до практичної реалізації ідеї Нової української школи}

\section{Олена Сергіївна Хмельницька}

кандидат педагогічних наук, старший викладач кафедри педагогіки

ДВНЗ «Переяслав-Хмельницький державний педагогічний університет імені Григорія Сковороди»,

вул. Сухомлинського, 30, м. Переяслав-Хмельницький, Київська обл., Україна, 08401

Дата надходження статті: 30 листопада 2018 р. Стаття прийнята до друку: 21 лютого 2019 р.

\section{Abstract}

The article describes the main components of the teacher's professional training for the implementation of the idea of the New Ukrainian School, the role of integrating the theoretical and practical training of future teachers, and the peculiarities of the 
introduction of dual education into pedagogical activity. The innovative methods, technologies and forms of educational activity organization during the study of theoretical foundations of pedagogy, the peculiarities of their application in practical and seminary classes, have been separated, in particular, individualized and differentiated learning, group forms of activity, mixed and adaptive learning, a digital storytelling, a personalized learning, an inverted class, a virtual classroom, a gaming education, STEM education, a training, debate, etc. The main aspects that promote the professional competencies of students, their technological and personal readiness, and the formation of a competitive specialist in this field during the pedagogical practice are investigated.

The correlation between theory and practice in pedagogical activity has certain regularities. The objective laws of pedagogical activity determine only its main direction. The forms of manifestation of pedagogical patterns are multivariate; in different situations they can be different and determined by specific conditions. The theory of pedagogy gives only a possible choice of methods, techniques, means and forms of content implementation, but can not predict many specific situations, give timely guidance for each case.

The integration of theoretical and practical future teachers' training contributes to activating cognitive activity of students, forming a holistic view of the future profession, creating the optimal conditions for gaining strong knowledge and skills in the work. A student integrates into the school system, improves the theoretical and methodological knowledge, practical skills and examines the age and psychological characteristics of children.

The New Ukrainian School is designed to form a person capable of being successful in life, holistic and versatile, initiative, patriot with an active position, an innovator capable of changing the world. To accomplish the above tasks, a professional teacher must possess a range of competencies such as informational, digital, research, civic, linguistic-communicative, social, technological, etc. An educational activity at the institution of higher education is constructed in such a way as to ensure the formation and improvement of the professional competences necessary for the New Ukrainian School teacher. 
The specificity of the professional training of future teachers is to ensure continuity and integration of the theoretical and practical components of training.

Key words: New Ukrainian School, competencies, innovative technologies, integration, theoretical and practical training, vocational training, educational activity, teaching methods, forms of training.

\section{References}

1. Vajnola, P.X. (2017). Metodyka vykladannya dyscyplin socialno-pedagogichnogo cyklu. Navchalnyj posibnyk [Methodology of teaching disciplines of the sociopedagogical cycle]. Centr uchbovoyi literatury. Kiev [in Ukrainian].

2. Gushynecz, N.O. (2008). Innovacijni metody i formy provedennya seminarskyx zanyat [Innovative methods and forms of seminars]. Retrieved from URL: http://conf.vntu.edu.ua/humed/2008/txt/gushinez.php.

3. Zakon Ukrayiny «Pro osvitu» (2017). [Law of Ukraine «On Education»]. Retrieved

from https://ru.osvita.ua/legislation/law/2231/.

4. Koncepciya Novoyi ukrayinskoyi shkoly (2016). [Concept of the New Ukrainian School]. Retrieved from https://www.kmu.gov.ua/storage/app/media/reforms/ukrain ska-shkola-compressed.pdf.

5. Koncepciya pidgotovky faxivciv za dualnoyu formoyu zdobuttya osvity (2018). [Concept of specialists' training on the dual form of education]. Retrieved from https://www.kmu.gov.ua/ua/news/koncepciya-pidgotovkifahivciv-za-dualnoyu-formoyu-zdobuttya-osviti.

6. Lyashenko, O. \& Koczur, V. (2018). Na shlyaxu do novoyi ukrayinskoyi shkoly [On the way to a new Ukrainian school]. Ridna shkola. 3-4 (1058), 8-10 [in Ukrainian].

7. Makovska, O.A. (2011). Praktychni zanyattya yak forma navchalno-vyxovnogo procesu u faxovij pidgotovci majbutnogo vykladacha vyshhogo navchalnogo zakladu [Practical lessons as a form of the teaching and bringingup process in the professional training of the future teacher 
of a higher educational establishment]. Retrieved from http://bo0k.net/index.php?p=achapter\&bid=14251\&chapte $\mathrm{r}=1$ [in Ukrainian].

8. Pometun, O.I. (2007). Encyklopediya interaktyvnogo navchannya. [Encyclopedia of interactive learning]. Kiev: A.S.K. [in Ukrainian].

9. Sergijchuk, O.M. \& Onyshhenko, N.P. (2012). Formuvannya gotovnosti majbutnix uchyteliv do profesijnoyi diyalnosti u procesi pedagogichnoyi praktyky [Formation of the future teachers' readiness for a professional activity in the process of pedagogical practice]. Pereyaslav-Xmelnyczkyj: Vydavnycztvo PP «SKD» [in Ukrainian].

10. Sysoyeva, S. (2011). Interaktyvni texnologiyi navchannya doroslyx [Interactive adult teaching technologies]. VD «EKMO», Kiev [in Ukrainian].

\section{Вступ}

На сучасному етапі впровадження ідей Нової української школи та модернізації змісту освіти, конче необхідна підготовка компетентнісного фахівця, учителя, який зможе у своїй практичній діяльності спрямовувати дітей та молодь до якісного життя у суспільстві. Орієнтуючись на Державний стандарт та типові освітні програми, учитель повинен вміло обирати та формувати інтегрований та автономний спосіб подання змісту 3 освітніх галузей Стандарту, добирати дидактичний матеріал, ефективні методики та технології навчання і виховання, орієнтуватися на індивідуальні можливості та пізнавальні запити учнів, практичне застосування ними одержаних знань та навичок поведінки в життєвих ситуаціях. Тому нові тенденції професійної підготовки майбутнього фахівця спрямовані на набуття студентами педагогічних закладів вищої освіти, майбутніми учителями ряду загальних та професійних компетентностей, вміння нестандартно та креативно мислити, бути активними, раціонально оволодівати новими знаннями та технологіями, здатними до навчання впродовж життя тощо. 
Питання підготовки вчителя для реалізації завдань Нової української школи озвучується відомими науковцями, зокрема Н. Бібік, М. Вашуленко, Л. Гріневич, В. Коцур, О. Пометун, О. Савченко та ін. Теоретичні основи інноваційної діяльності педагогів висвітлено у публікаціях I. Дичківської, В. Моляко, І. Підласого, Б. Сазонова тощо. Психологічну готовність вчителів до нововведень у професійній діяльності досліджено М. Боришевським, Г. Головіним, Н. Клокар, Л. Мітіною, О. Соснюк, О. Францевою та ін.

Увага науковців до цього питання $є$ доречною та потребує дослідження можливостей якісної професійної підготовки майбутніх учителів. Тому метою написання статті $\epsilon$ дослідження шляхів удосконалення теоретичної та практичної підготовки майбутніх учителів у контексті розбудови Нової української школи. Серед завдань провідним є виокремлення головних аспектів, що сприяють підвищенню професійних компетентностей майбутніх учителів, їх технологічної та особистісної готовності, формування конкурентоспроможного фахівця у цій галузі.

\section{Матеріали і методи досліджень}

Для досягнення поставлених завдань використовувалися такі теоретичні методи дослідження як аналіз наукової та методичної літератури з досліджуваної проблеми, моделювання ситуацій, синтез та узагальнення зібраних даних.

\section{Результати та їх обговорення}

Закон України «Про освіту», який окреслює правові норми організації діяльності закладів освіти, був прийнятий Верховною Радою 5 вересня 2017 року. Закон характеризується рядом змін. Зокрема, терміном навчання 12 років, збільшенням автономії закладів освіти та оплати вчителям, правилами атестації вчителів та підвищення їх кваліфікації, уточненнями особливостей управлінської діяльності та обрання директорів шкіл, наданням ширших прав державній мові навчання. 31 вересня 2017 року за Новою українською школою почали працювати пілотні навчальні заклади, а 31 вересня 2018 року всі початкові навчальні заклади України. 
Прийняття Закону України «Про освіту» визначає нові вимоги до підготовки висококваліфікованих вчителів Нової української школи. Для реалізації цього закону у закладах вищої освіти мають здійснюватись інтеграція теоретичної та практичної підготовки майбутніх учителів, застосовуватись новітні методики та технології навчання i виховання, формуватись ключові компетентності особистості та запроваджуватись нові форми навчальної діяльності (Закон України «Про освіту», 2017).

Підготовка

висококваліфікованого, конкурентоспроможного фахівця освітньої галузі можлива завдяки поєднанню міцних та глибоких теоретичних знань 3 практичними. Сучасні вимоги до педагога та процесу його підготовки в навчальному закладі зумовлені багатьма факторами: інтенсивною інформатизацією, диференціацією та інтеграцією наук, ускладненням функцій педагогічної діяльності тощо. Усе це вимагає від учителя не лише поінформованості, але й неперервного розвитку професійних якостей. Суттєву роль у формуванні готовності майбутнього вчителя до професійної діяльності відіграє його практична підготовка - важлива складова всієї системи професійної підготовки (Сергійчук, Онищенко, 2012).

Отримані під час теоретичної підготовки знання, допомагають оптимально добирати методи та форми роботи, засоби досягнення мети діяльності, вміння орієнтуватися в різнопланових педагогічних ситуаціях, передбачати та оцінювати результативність своєї професійної діяльності тощо.

Співвідношення між теорією та практикою у педагогічній діяльності має певні закономірності. Об'єктивні закони педагогічної діяльності визначають лише її основне направлення. Форми прояву педагогічних закономірностей визначаються певними ситуаціями та конкретними умовами. Педагогічна теорія дає лише можливий вибір методів, прийомів, засобів та форм реалізації змісту, проте не може передбачити різноманітність ситуацій та спланувати їх вирішення завчасно. 
Практична підготовка передбачає проходження різних видів практик та діяльність студента на практичних та семінарських заняттях, а також за допомогою інших форм i видів навчальної роботи.

Інтеграція теоретичної та практичної підготовки майбутніх педагогів сприяє активізації пізнавальної діяльності студентів, формуванню цілісного уявлення про майбутню професію, створенню оптимальних умов для здобуття міцних знань та навичок у роботі.

Щоб підвищити якість підготовки майбутніх учителів, потрібно інтенсифікувати та оптимізувати навчальний процес у закладі вищої освіти, забезпечити ефективність пізнавальної діяльності студентів та оптимально сприятливі умови навчання. Це передбачає побудову навчальної діяльності на принципах індивідуалізації навчання, тобто врахуванні індивідуально-психічних можливостей студентів, їхніх схильностей до роботи за фахом, до самоорганізації, саморозвитку й успішності навчання. Це забезпечить розвиток професійних здібностей, формування особистісних якостей i, відповідно, психічної готовності до професійної діяльності.

Нова українська школа покликана формувати особистість, здатну бути успішною у житті, цілісно і різнобічно розвиненою, ініціативною, патріотом з активною позицією, інноватором, здатним змінювати світ. Щоб реалізувати вищепоставлені завдання учитель-професіонал має володіти рядом компетентностей таких як інформаційна, цифрова, дослідницька, громадянська, мовно-комунікативна, соціальна, технологічна та ін. Навчально-виховна діяльність у закладі вищої освіти побудована таким чином, щоб забезпечити формування та вдосконалення професійних компетентностей необхідних учителю Нової української школи (Концепція Нової української школи, 2016).

Під час теоретичної підготовки студентів (майбутніх учителів) вчать застосовувати інформаційно-комунікаційні технології для створення, пошуку, оброблення та обміну інформацією у житті. У студентів формують медіаграмотність, етику спілкування у інформаційному просторі, 
вчать працювати на електронних платформах. Майбутні учителі оволодівають інноваційними технологіями навчання, як змішане і адаптивне навчання, цифровий сторітеллінг, персоналізоване навчання, перевернутий клас, віртуальний клас, гейміфікація навчання, STEM освіта тощо (Ляшенко, Коцур, 2018).

На практичних та семінарських заняттях $з$ педагогіки практична складова представлена низкою інноваційних методів, технологій та форм роботи у групах студентів. Серед них індивідуалізовані та диференційовані форми роботи. Проводячи роботу у групах, викладач сприяє залученню всіх студентів з урахуванням рівня їх розвитку та можливостей сприйняття матеріалу. Студент розвиває свої індивідуальні професійні риси під час вирішення творчих завдань, коли залучається його власний життєвий досвід і отримані знання. Самооцінка студентів стає головним фактором оцінювання власних досягнень. Навчання, у такому разі, будується на основі спілкування між людьми для отримання нових знань. Викладач стає посередником між студентами і навчальним матеріалом.

Під час групової роботи студент набуває певних навичок та вдосконалює власні компетентності такі як відповідальність за спільну та індивідуальну діяльність, вміння відстоювати власну позицію, співпрацювати, обмінюватися інформацією, виконувати ролі, залежно від обставин, лідера, автора, репортера, спостерігача. Роль викладача у такій роботі полягає у правильному формулюванні завдання та забезпеченні взаємодії груп, підготовці цікавого заохочувального матеріалу, внесенні коректив, спрямуванню роботи груп тощо (Гушинець, 2008).

Інтерактивні методи навчання передбачають діяльність учасників та групову взаємодію. Їх застосовують з метою порушити монотонність і урізноманітнити практичні заняття; сприяти формуванню партнерських стосунків; розвивати співпрацю та творчий підхід; зорієнтувати навчання на практичну професійну діяльність; залучити до співпраці більшу кількість студентів. 
Інтерактивна діяльність

передбачає непередбачуваність. Тобто, застосування інтерактивних методів та алгоритм їх реалізації добираються відповідно вимог конкретної педагогічної ситуації. Серед методів інтерактивної взаємодії можуть бути: лекції-презентації; дискусії; тренінги; ділові і рольові ігри; моделювання ситуацій; мозковий штурм тощо.

За класифікацією Р. Вайноли, можна виокремити інтерактивні форми проведення практичних занять. Серед них заслуховування доповідей, міні-захист інноваційних програм та проектів навчально-виховної роботи; ретроспективний аналіз педагогічних явищ та навчальновиховних ситуацій; написання анотацій та рецензій; заповнення таблиць; конкурси; ділові та рольові ігри; педагогічні бесіди; диспути; розробка картотек; демонстрація технік та аналіз методик педагогічної діяльності; розробка демонстраційних та ілюстративних матеріалів, зокрема рекламної та інформаційної продукції, відеороликів; розробка планів-конспектів уроків, сценаріїв, навчальновиховних заходів; акції, фестивалі, тематичні тижні тощо (Вайнола, 2017).

Серед педагогічних засобів активізації навчального процесу у закладах вищої освіти особливе місце належить дидактичній грi, яка характеризується цілеспрямованою організацією навчально-професійної діяльності майбутнього фахівця. Процес навчання побудований на застосуванні різних видів ділових ігор: імітаційних, операційних, рольових, діловий театр тощо. Зокрема, «Мозковий штурм» як ефективний метод колективної дискусії, пошуку оптимальних рішень у процесі спільного висловлювання та обговорення думок. Він дає можливість за нетривалий час висловитись великій кількості студентів, що є передумовою прийняття найбільш розумного рішення.

Викладач пропонує студентам різні педагогічні cumуаціï, штучно їх створює, проводить тренінги та спрямовує до вирішення поставлених педагогічних завдань у інтерактивному колі. Такі форми роботи - це діалог, різнопланове співробітництво учасників (студента 3 колегами 
та викладачем) навчального процесу з метою колективного розв'язання ситуації та спільного пошуку рішень. Вони спрямовані на пошук ефективних ідей, розширення i можливу зміну власної позиції та кута зору, чесність у взаємовідносинах. Як доводять дослідження, під час групових обговорень i дискусій відбувається якісне засвоєння 50\% необхідного матеріалу.

Ще однією формою групової роботи є дискусіӥ-це словесний обмін ідеями, думками з будь-якої теми. Користь дискусій полягає у можливості активізувати розумову діяльність студентів, умінні висловлювати та відстоювати власну позицію, використовувати набуті теоретичні та практичні знання (Маковська, 2011; Пометун, 2007; Сисоєва, 2011).

Під час педагогічної практики закріплюються навички, напрацьовані на практичних і семінарських заняттях щодо готовності до професійної самореалізації. Вдосконаленню практичної підготовки сприяють спостереження студентів за проведенням уроків у школах учителями. Під час проведення пробних уроків студенти виявляють свої індивідуальні особливості та творчі здібності, креативне мислення, педагогічну інтуїцію, творчу уяву, асоціативне мислення, інтелектуальну активність та, звичайно, теоретичну підготовку.

Для більш глибокого розуміння інтеграції теоретичної та практичної підготовки, завдяки повторюваності педагогічних завдань та ситуацій, педагог може звертатися до вже існуючого педагогічного досвіду. Якщо вчитель не звертається до досвіду провідних педагогів минулого, власного педагогічного досвіду та передового досвіду колег, то кожного разу починатиме справу спочатку. Ситуація складеться так само, за умови використання обмежених методів та засобів у роботі. Педагогічна практика через застосування нових освітніх технологій, новаторських підходів у педагогіці постійно розвивається, збагачується та змінюється. Практика - це невичерпне джерело педагогічних спостережень та знахідок, цілей та відкриттів. Провідні сторінки в історії педагогічної думки належать педагогам- 
новаторам, які ціленаправлено поєднували теоретичні знання 3 практичним використанням, узагальнення 3 досвідом, новаторські ідеї 3 експериментальною перевіркою. Новаторський характер чітко відображається у творчій діяльності А. Макаренка та В. Сухомлинського. Теоретичні аспекти їх навчально-виховної діяльності були підкріплені практичним шляхом (Маковська, 2011; Пометун, 2007; Сисоєва, 2011).

Наприкінці січня 2018 року було прийнято Концепцію підготовки фахівців за дуальною формою здобуття освіти в Україні. У педагогічних університетах дуальна освіта представлена практичною складовою. На практичну діяльність майбутнім вчителям відводять до 70\% часу. Таке співвідношення практичної підготовки і навчання підвищує конкурентоздатність молодих педагогів.

Основне завдання дуальної форми навчання - це усунення основних недоліків традиційних форм і методів навчання майбутніх кваліфікованих вчителів, подолання розриву між теорією і практикою, освітою й школою, та підвищення якості підготовки кваліфікованих кадрів із урахуванням вимог роботодавців у рамках нових організаційно-відмінних форм навчання.

Студент поєднує навчання з практичною діяльністю у школі. Він має наставника. Статус наставника закріплений у угоді з навчальним закладом, наказі університету. За свою роботу зі студентом вчитель отримує оплату (Концепція підготовки фахівців за дуальною формою здобуття освіти, 2018).

Практична підготовка допомагає студентам, майбутнім учителям перевірити власні теоретичні знання, накопичені у закладі вищої освіти та становить підгрунтя для поглибленого засвоєння проблем, що мають місце у педагогічній сфері. А також, вивчити та проаналізувати реальні ситуації, самостійно приймати рішення, обгрунтовуючи їх доцільність перед керівником практики. Майбутній фахівець навчається роботі в педагогічному колективі, отримує навички професійного спілкування. 
Під час педагогічної практики студенти вчаться розв'язувати різнопланові педагогічні завдання, в конкретних ситуаціях прогнозувати хід навчально-виховного процесу i знаходити оптимальні шляхи управління ним. Відбувається не тільки ознайомлення 3 сучасним станом організації навчально-виховного процесу у закладах освіти, 3 передовим педагогічним досвідом, формування фахових компетентностей кожного студента, але й надання допомоги навчально-виховним установам. Загалом це інтенсивна самоосвітня і самовиховна робота майбутніх педагогів, перевірка їхньої готовності до майбутньої професійної діяльності.

Студент інтегрується в шкільну систему, вдосконалює теоретичні та методичні знання, практичні навички, вивчає вікові та психологічні особливості дітей. Цю діяльність оцінює вчитель та методисти з кафедр університету.

\section{Висновки}

Таким чином, аналіз особливостей фахової підготовки майбутніх учителів в закладах вищої освіти визначається розумінням мети та змісту певного виду діяльності; інтеграцією теоретичних знань у практичній діяльності; спостереженням за роботою досвідченого фахівця-практика. Специфіка професійної підготовки майбутніх педагогів полягає у забезпечені наступності, неперервності та інтеграції теоретичної та практичної складових підготовки. Саме така творча, активна та цілісна діяльність у поєднанні 3 теоретичним підгрунтям та практичним застосуванням здобутих знань допоможе студентам у майбутньому стати професіоналами високого гатунку, здатними реалізувати провідні ідеї Нової української школи.

\section{Література}

1. Вайнола Р.X. Методика викладання дисциплін соціально-педагогічного циклу. Навчальний посібник. Київ : Центр учбової літератури, 2017. 140 с.

2. Гушинець Н.О. Інноваційні методи і форми проведення семінарських занять. URL: http://conf.vntu.edu.ua/ humed/ 2008/txt/gushinez.php 
3. Закон України «Про освіту» від 05.09.2017 р. URL: https://ru.osvita.ua/legislation/law/2231/

4. Концепція Нової української школи. URL: https://www.kmu.gov.ua/storage/app/media/reforms/ukrain ska-shkola-compressed.pdf

5. Концепція підготовки фахівців за дуальною формою здобуття освіти. URL: https://www.kmu.gov.ua/ ua/news/ koncepciya-pidgotovki-fahivciv-za- dualnoyu-formoyuzdobuttya-osviti

6. Ляшенко О., Коцур В. На шляху до нової української школи. Рідна школа. 2018. №3-4 (1058). С.8-10.

7. Маковська О.А. Практичні заняття як форма навчальновиховного процесу у фаховій підготовці майбутнього викладача вищого навчального закладу. URL: http://bo0k.net/index.php?p=achapter\&bid=14251\&chapte $\mathrm{r}=1$

8. Пометун О.І. Енциклопедія інтерактивного навчання. Київ: А.С.К., 2007. 144 с.

9. Сергійчук О.М., Онищенко Н.П. Формування готовності майбутніх учителів до професійної діяльності у процесі педагогічної практики: навчальнометодичний посібник. Переяслав-Хмельницький: Видавництво ПП «СКД», 2012. $171 \mathrm{c.}$

10. Сисоєва С. Інтерактивні технології навчання дорослих. Київ: ВД «ЕКМО», 2011. 324 с.

\section{Хмельницька О.С.}

\section{Професійна підготовка педагога до практичної реалізації ідеї Нової української школи}

\section{Анотація}

У статті охарактеризовано основні складові професійної підготовки педагога до реалізації ідеї Нової української школи, роль інтеграції теоретичної та практичної підготовки майбутніх учителів, особливості впровадження дуальної освіти у педагогічну діяльність. Виокремлено 
інноваційні методи, технології та форми організації навчально-виховної діяльності під час вивчення теоретичних основ педагогіки, особливостей застосування їх на практичних та семінарських заняттях, зокрема індивідуалізоване та диференційоване навчання, групові форми діяльності, змішане і адаптивне навчання, цифровий сторітеллінг, персоналізоване навчання, перевернутий клас, віртуальний клас, гейміфікація навчання, STEM освіта ,тренінги, диспути тощо. Досліджено головні аспекти, що сприяють підвищенню професійних компетентностей студентів, їх технологічної та особистісної готовності, формування конкурентоспроможного фахівця у цій галузі під час проходження педагогічної практики.

Ключові слова: Нова українська школа, компетентності, інноваційні технології, інтеграція, теоретична і практична підготовка, професійна підготовка, навчальна діяльність, методи навчання, форми навчання.

\section{Хмельницкая Е.С.}

\section{Профессиональная подготовка педагога к} практической реализации идеи Новой украинской Школы

\section{Аннотация}

В статье охарактеризованы основные составляющие профессиональной подготовки педагога к реализации идеи Новой украинской школы, роль интеграции теоретической и практической подготовки будущих учителей, особенности внедрения дуальной образования в педагогическую деятельность. Выделены инновационные методы, технологии и формы организации учебно-воспитательной деятельности при изучении теоретических основ педагогики, особенностей применения их на практических и семинарских занятиях, в частности индивидуализированное и дифференцированное обучение, групповые формы деятельности, смешанное и адаптивное обучение, цифровой сторителлинг, персонализированное обучение, перевернутый 
класс, виртуальный класс, геймификация обучения, STEM образование, тренинги, диспуты и тому подобное. Исследовано главные аспекты, способствующие повышению профессиональных компетенций студентов, их технологической и личностной готовности, формирования конкурентоспособного специалиста в этой области во время прохождения педагогической практики.

Ключевые слова: Новая украинская школа, компетентности, инновационные технологии, интеграция, теоретическая и практическая подготовка, профессиональная подготовка, учебная деятельность, методы обучения, формы обучения. 